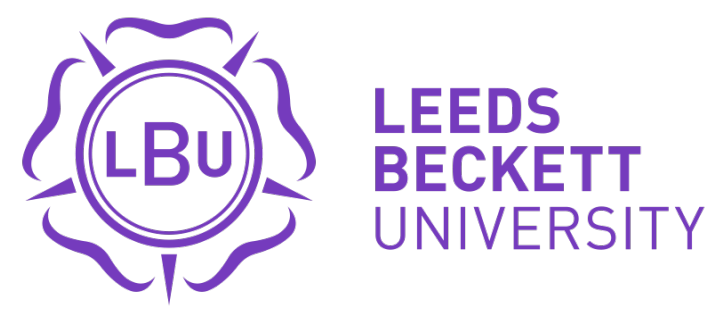

Citation:

Fearnley, D and Sutton, L and O'Hara, J and Brightmore, A and King, R and Cooke, CB (2012) Case study of a female ocean racer: prerace preparation and nutritional intake during the Vendee Globe 2008. International journal of sport nutrition and exercise metabolism, 22 (3). 212 - 219. ISSN $1526-484 X$

Link to Leeds Beckett Repository record:

https://eprints.leedsbeckett.ac.uk/id/eprint/264/

Document Version:

Article (Published Version)

The aim of the Leeds Beckett Repository is to provide open access to our research, as required by funder policies and permitted by publishers and copyright law.

The Leeds Beckett repository holds a wide range of publications, each of which has been checked for copyright and the relevant embargo period has been applied by the Research Services team.

We operate on a standard take-down policy. If you are the author or publisher of an output and you would like it removed from the repository, please contact us and we will investigate on a case-by-case basis.

Each thesis in the repository has been cleared where necessary by the author for third party copyright. If you would like a thesis to be removed from the repository or believe there is an issue with copyright, please contact us on openaccess@leedsbeckett.ac.uk and we will investigate on a case-by-case basis. 


\title{
Case Study of a Female Ocean Racer: Prerace Preparation and Nutritional Intake During the Vendée Globe 2008
}

\author{
Deborah Fearnley, Louise Sutton, John O’Hara, Amy Brightmore, \\ Roderick King, and Carlton Cooke
}

\begin{abstract}
The Vendée Globe is a solo round-the-world sailing race without stopovers or assistance, a physically demanding challenge for which appropriate nutrition should maintain energy balance and ensure optimum performance. This is an account of prerace nutritional preparation with a professional and experienced female racer and assessment of daily nutritional intake (NI) during the race using a multimethod approach. A daily energy intake (EI) of $15.1 \mathrm{MJ} /$ day was recommended for the race and negotiated down by the racer to 12.7 $\mathrm{MJ} /$ day, with carbohydrate and fluid intake goals of $480 \mathrm{~g} /$ day and 3,020 ml/day, respectively. Throughout the 99-day voyage, daily NI was recorded using electronic food diaries and inventories piloted during training races. NI was assessed and a postrace interview and questionnaire were used to evaluate the intervention. Fat mass (FM) and fat-free mass (FFM) were assessed pre- (37 days) and postrace (11 days) using dual-energy $\mathrm{X}$-ray absorptiometry, and body mass was measured before the racer stepped on the yacht and immediately postrace. Mean EI was $9.2 \mathrm{MJ} /$ day $(2.4-14.3 \mathrm{MJ} /$ day), representing a negative energy balance of $3.5 \mathrm{MJ} / \mathrm{day}$ under the negotiated EI goal, evidenced by a 7.9-kg loss of body mass (FM $-7.5 \mathrm{~kg}$, FFM $-0.4 \mathrm{~kg}$ ) during the voyage, with consequent underconsumption of carbohydrate by $\sim 130 \mathrm{~g} / \mathrm{day}$. According to the postrace yacht food inventory, self-reported EI was underreported by $7 \%$. This intervention demonstrates the practicality of the NI approach and assessment, but the racer's nutrition strategy can be further improved to facilitate meeting more optimal NI goals for performance and health. It also shows that evaluation of NI is possible in this environment over prolonged periods, which can provide important information for optimizing nutritional strategies for ocean racing.
\end{abstract}

Keywords: sailing, macronutrient intake, food inventory

Sailing is a physically demanding, arduous activity. Known as the "Everest of the seas," the Vendée Globe is a solo race in which demands are magnified with no crew members to share tasks. Energy requirements are high during solo sailing, often resulting in weight loss as a consequence of energy intake (EI) not matching energy expenditure (EE; Myers, Leamon, Nevola, \& Llewellyn, 2007).

Sleeping and eating, often not the highest priority, are difficult in the frequently changing harsh environmental conditions. Weather, rather than food availability, affects eating patterns; constant winds have been reported to entail less sail maneuvering and more time to rest and recover. The weight of food taken on board is a major issue affecting nutrition and may be compromised due to the perception that a surplus will reduce yacht speed.

Branth et al. (1996) and Bigard et al. (1998) used food inventories to record nutritional intake of 11 male sailors during the first three legs in an offshore crewed race around the world and during a four-stage Solitaire-Le Figaro solo race (mean stage duration 3.5 days), respectively. Myers et al. (2007) measured EE of a 36-year-old

The authors are with the Carnegie Research Institute, Leeds Metropolitan University, Leeds, UK. man competing in a 13-day single-handed transatlantic yacht race. The studies were not representative of a solo offshore prolonged race, which has not been investigated in female sailors during the Vendée Globe.

The 2008 race started and finished at Les Sables d'Olonne, France, covering approximately 24,840 miles. Without stopovers or external help competitors circumnavigated the globe with prevailing winds in a $60-\mathrm{ft}(\sim 18$ m) open-class yacht, down to the South Atlantic, east past the Cape of Good Hope, and through the notorious Southern Ocean, known for its extreme weather conditions. After Cape Horn competitors sailed back north into the Atlantic Ocean. The meteorological ranges of wind speed, temperature, and humidity were likely very variable during the different phases of the race. The Southern Ocean is known to be a very demanding phase of the race in comparison with the Doldrums, for example. Therefore, the relationship of EI to EE would not be expected to be consistent during the different phases of the race.

\section{The Athlete}

Institution ethical approval was acquired for the study after the racer presented for support. The racer gave 
written informed consent to take part and for the results to be submitted for publication. Applied sport science support was provided for training and race preparation and concluded postrace with feedback and debrief. The 36-year-old woman was an experienced racer (height $173 \mathrm{~cm}$, body mass $83.9 \mathrm{~kg}$, fat mass [FM] $28.0 \mathrm{~kg}$, fat-free mass [FFM] 52.8 $\mathrm{kg}$, bone mineral content $3.1 \mathrm{~kg}$ ) who had been sailing professionally for 9 years. She had previous experience in team and single-handed global circumnavigation but had never previously competed in the Vendée.

\section{Prerace Preparation}

Before the voyage, the racer received intensive individualized nutrition education to increase her awareness of prescribed nutrition intake (NI) goals and recording of dietary intake. Despite previous studies suggesting that collecting dietary intake data using food records in this environment is impractical (Myers et al., 2007), this study aimed to overcome these difficulties by adopting a multimethod approach to increase validity and reliability. Purposely designed inventories and electronic food diaries were piloted during training voyages and adapted by the racer and nutritional support team. Consumption of food and fluid was recorded for the duration of the 99-day race on waterproof paper. These temporary records were entered into the diary at the end of each day.

Due to potential attention problems arising from the demanding requirements of sailing maneuvers to maintain optimal race pace, additional verification was established by reference to the inventory at the completion of the voyage to validate reported EI. Weights of all foods taken on board were known, and the racer agreed not to discard any foods overboard.

Dual-energy X-ray absorptiometry (DXA) assessments for the estimation of FM and FFM were undertaken 37 days before and 11 days after the Vendée. The dates of the assessments were structured due to the constraints of the race. Participants of the Vendée Globe are expected to be in France 2 weeks before the race, and time was required for travel back to the UK after the race. Body mass was measured on calibrated scales immediately before the racer stepped onto the yacht and immediately postrace.

\section{Dietary Prescription}

Basal metabolic rate, calculated as $6.3 \mathrm{MJ} /$ day using the Schofield equation (1985), was multiplied by a physical activity level to estimate total energy requirement. Noting previous research reported on male participants, a physical activity level of 2.0-2.4 was assigned, categorized as strenuous work or rigorous training (Black, 2001). Myers et al. (2007) reported mean physical activity levels of 2.1 and 2.5 during the most physically demanding days of solo yacht racing. Total energy requirement was therefore calculated at 12.7-15.1 MJ/day. A daily average target was prescribed, as the prediction of light and heavy sailing days was not possible due the likely variation in weather conditions and the lack of scientific evidence for the precise energy demands of the different phases of the race.

The racer's self-selected food plan allowed 8.4 MJ/ day. Discussion revealed concern regarding yacht efficiency and food wastage with a greater food allowance carried but not consumed in previous voyages. A minimum EI goal of 12.7 MJ/day was negotiated based on an educational approach that highlighted likely problems of inadequate EI. Water produced on board was used both to hydrate freeze-dried food and to prepare beverages to achieve a minimum fluid intake goal of 3,020 $\mathrm{ml} /$ day. This was set based on the guidelines of $1 \mathrm{ml} /$ $\mathrm{kcal}$ (Kleiner, 1999). As caution is recommended when basing macronutrient intake goals on percentage values, carbohydrate intake relative to body mass was calculated based on the minimum intake guidelines $\left(6 \mathrm{~g} \cdot\right.$ day $^{-1}$. $\mathrm{kg}^{-1}$ ) recommended by the American College of Sports Medicine (American Dietetic Association et al., 2009), producing values comparable to $60 \%$ of total energy requirement (498 g/day and $480 \mathrm{~g} /$ day, respectively), the latter agreed to by the racer. It was anticipated that by setting a carbohydrate intake goal, other macronutrient intakes would fall into place accordingly, since it is reported that a high carbohydrate intake facilitates meeting total energy requirement and controlling body mass (Williams, 1995). Given the wide range of activities the racer would engage in, providing one average intake goal was deemed the simplest approach to meeting her nutritional requirements. A 100-day menu plan based on foods trialed during training voyages was produced. Food was packed into ten 10-day bags, each different to avoid menu fatigue (Table 1). Also included in the racer's menu to meet total EI requirements was free access to a powdered sports drink and energy gels. A 10-day emergency food bag was carried on board as a requirement outlined by race organizers; this was excluded from inventory calculations. The use of micronutrient and meal-replacement supplements such as Complan was discussed with the racer. The racer chose to take a multivitamin and mineral complex and cod-liver-oil tablet.

NI was assessed using NetWISP nutritional-analysis software (2004, Tinuviel Software, Anglesey, UK). Manufacturer's declaration of content was entered manually for foods not included in the program. Data entries were checked on two occasions by separate investigators. Mean daily EI was calculated from food taken on board prerace minus leftover food postrace (Bigard et al., 1998; Branth et al., 1996) and compared with the self-reported diary. Postrace interview and questionnaire validated data recording and clarified the racer's food preferences, nutritional strategies, perceived effects of nutrition on performance, ability to meet intake goals, and task of recording NI.

\section{Assessment of NI}

According to the inventory, mean EI met $72 \%$ of the negotiated EI goal (Table 2), compared with $82 \%$ of energy requirements reported by Branth et al. (1996), 
Table 1 Example Contents of 10-Day Food Bag

\begin{tabular}{|c|c|c|c|c|c|}
\hline Brand & Product & Flavor & Quantity & Carbohydrate ${ }^{a}$ & Energy \\
\hline \multirow[t]{2}{*}{ Mars } & Tracker bar & Chocolate chip & $3 \times 26 g$ & 15 & 125 \\
\hline & & Raisin & $2 \times 26 \mathrm{~g}$ & 15 & 125 \\
\hline \multirow[t]{2}{*}{ Cadbury } & Brunch bar & Raisin & $3 \times 35 \mathrm{~g}$ & 25 & 110 \\
\hline & & $\begin{array}{l}\text { Cranberry and } \\
\text { orange }\end{array}$ & $3 \times 35 \mathrm{~g}$ & 25 & 110 \\
\hline Haribo & Haribo minis & & 10 packets & 35 & 140 \\
\hline Soreen & Malt loaf & & $1 \times$ loaf & 160 & 766 \\
\hline \multirow[t]{3}{*}{ Dole } & Fruit and juice pot & $\begin{array}{l}\text { Mandarin in grape } \\
\text { nectar }\end{array}$ & $1 \times 113 \mathrm{~g}$ & 15 & 70 \\
\hline & Dried apricots & & $1 \times 100 \mathrm{~g}$ & 35 & 295 \\
\hline & Dried berries & Berry mix & $1 \times 100 \mathrm{~g}$ & 60 & 260 \\
\hline \multirow[t]{6}{*}{$\begin{array}{l}\text { Alpine Aire Foods, } \\
\text { USA }\end{array}$} & Granola & Strawberry honey & 1 packet & 135 & 645 \\
\hline & & Blueberry honey & 1 packet & 110 & 555 \\
\hline & Leonardo fettuccine & & 1 packet & 90 & 640 \\
\hline & $\begin{array}{l}\text { Stroganoff flavored with beef } \\
\text { and noodles }\end{array}$ & & 1 packet & 80 & 640 \\
\hline & $\begin{array}{l}\text { Spaghetti marinara and mush- } \\
\text { rooms }\end{array}$ & & 1 packet & 110 & 620 \\
\hline & Sierra chicken & & 1 packet & 110 & 645 \\
\hline \multirow[t]{4}{*}{$\begin{array}{l}\text { Expedition Foods, } \\
\text { UK }\end{array}$} & Hot cereal start with sultana & & $2 \times 125 \mathrm{~g}$ & 80 & 560 \\
\hline & Hot cereal start with mango & & $2 \times 150 \mathrm{~g}$ & 75 & 660 \\
\hline & Porridge and strawberries & & $1 \times 150 \mathrm{~g}$ & 105 & 800 \\
\hline & Porridge and sultanas & & $1 \times 150 \mathrm{~g}$ & 85 & 755 \\
\hline \multirow[t]{3}{*}{ Natural High, USA } & Stroganoff and beef & & $1 \times 83 \mathrm{~g}$ & 45 & 325 \\
\hline & Fettuccine primavera & & $1 \times 64 \mathrm{~g}$ & 45 & 240 \\
\hline & Chicken and broccoli & & $1 \times 67 \mathrm{~g}$ & 45 & 260 \\
\hline \multirow[t]{2}{*}{ Batchelor's } & Super noodles & Chicken & $2 \times 100 \mathrm{~g}$ & 25 & 180 \\
\hline & & Beef & $2 \times 100 \mathrm{~g}$ & 25 & 180 \\
\hline \multirow[t]{2}{*}{ Dolmio Express } & Pasta & Fusilli & $4 \times 100 \mathrm{~g}$ & 30 & 145 \\
\hline & Sauce & Tomato & $4 \times 100 \mathrm{~g}$ & 5 & 90 \\
\hline Morrisons & Instant mash & Cheese and chive & $1 \times 100 \mathrm{~g}$ & 15 & 90 \\
\hline \multirow[t]{6}{*}{$\begin{array}{l}\text { Backpackers } \\
\text { Pantry, US }\end{array}$} & Muesli & Cinnamon & 1 packet & 120 & 755 \\
\hline & Granola & Blueberry & 2 packets & 65 & 290 \\
\hline & Mash & Cheese and bacon & 2 packets & 70 & 210 \\
\hline & Macaroni and cheese & & 2 packets & 125 & 820 \\
\hline & Pasta and vegetable Parmesan & & 4 packets & 60 & 495 \\
\hline & Lasagna & & 1 packet & 105 & 760 \\
\hline
\end{tabular}

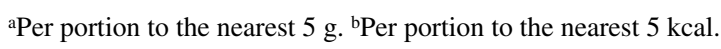


for whom higher intakes may have been attributable to feedback permissible in their study. Feedback was not possible during the Vendée as this was against the rules. EI would not have been to the detriment of energy used to facilitate metabolic processes since energy availability did not fall below $0.1 \mathrm{MJ} \cdot \mathrm{kg} \mathrm{FFM}^{-1} \cdot$ day $^{-1}$ (Loucks, 2004). Nevertheless, a mean EI of $\sim 10.5 \mathrm{MJ} /$ day (0.2 MJ $\cdot \mathrm{kg} \mathrm{FFM}^{-1} \cdot$ day $^{-1}$ ) would have been more appropriate to maintain energy balance.

Consequently, carbohydrate was underconsumed by $\sim 130 \mathrm{~g} /$ day in relation to the intake goal (480 g/day; Table 2). In absolute values mean fat intake was $\sim 4 \mathrm{~g} /$ day lower (Table 2) than the expected minimum intake $(67 \mathrm{~g} /$ day) but not to the detriment of carbohydrate intake, as evidenced in previous studies (Bigard et al., 1998; Branth et al., 1996). Mean protein intake (77 g/day, Table 2) was insufficient based on guidelines for athletes of 1.2-1.7 $\mathrm{g} \cdot \mathrm{kg} \mathrm{BM}{ }^{-1} \cdot$ day $^{-1}$ (American Dietetic Association et al., 2009). The racer was expected to consume $\sim 100 \mathrm{~g} /$ day based on calculations relative to body mass, which similarly provided a $15 \%$ contribution to total energy requirements. She did not meet the athlete guidelines but was able to maintain protein intake above the UK reference value of $0.75 \mathrm{~g} \cdot \mathrm{kg} \mathrm{BM}{ }^{-1} \cdot$ day $^{-1}$.

Inventory and reported percentage macronutrient contributions to total energy intake were adequate (Tables 2 and 3 , respectively), evidence that the racer consumed food in the recommended proportions of total energy intake. A higher EI would be necessary to achieve higher absolute intakes, emphasizing the importance of recommending nutritional requirements in absolute values relative to body mass.

The racer exceeded prescribed energy, carbohydrate, and fluid intake goals on some occasions (Table 3). Low NI was reported on Day 2, attributable to the racer's perceived high physical demands at the beginning of the race. The postrace interview indicated that she was unable to find time to boil a kettle to hydrate freeze-dried meals during the first 3-4 days. This was due to the bad weather that hit the Bay of Biscay and the effort required to weather the storm when others in the fleet were being forced to retire or having to return to port to make repairs. Furthermore, the racer had not fully developed trust in the autopiloting system and thus wanted to remain at the helm throughout this period. This limited her ability to consume substantive calories, despite having taken on board fresh pasta-based meals for that period. Motion sickness as a potential to affect nutritional intake was not reported by the racer during this phase or throughout the entire race. Mean total fluid intake was 3,612 $\mathrm{ml} /$ day comprising voluntary fluid intake (defined as fluid consumed independently of that included in foods) and fluid from food, which was above the prescribed minimum target intake goal $(3,020 \mathrm{ml} /$ day $)$. Over the duration of the voyage, mean voluntary fluid intake $(2,813 \mathrm{ml} /$ day $)$ fell short of the prescribed intake goal, although intakes ranged from 500 to $5,800 \mathrm{ml} /$ day. Reported voluntary intakes were greater than those evidenced previously in prolonged offshore racing. Bigard et al. (1998) reported mean voluntary fluid intake of 2,652 $\pm 125 \mathrm{ml} /$ day, which decreased with the duration of each stage, but this was not evident in the current study. The racer suggested that this was attributable to her raised awareness through her recording of fluid intake.

Self-reported EI was underreported by $7 \%$ (0.6 $\mathrm{MJ} /$ day) in comparison with the yacht's food inventory. Underreporting has been observed to range from $4 \%$ to 37\% (Black, 2001; Hill \& Davies, 2001), and accuracy decreased with duration of recording period. A multimethod approach accounted for this within the inventory. Since weights of all foods and fluids taken on board were known, it could be argued that the gold standard

Table 2 Energy and Macronutrient Intake According to Yacht Inventory

\begin{tabular}{lccccc}
\hline & $\begin{array}{c}\text { Percentage } \\
\text { contribution }\end{array}$ & $\begin{array}{c}\text { Sport nutrition } \\
\text { guidelines (\%) }\end{array}$ & $\begin{array}{c}\text { Mean intake } \\
\text { per day }\end{array}$ & $\begin{array}{c}\text { Relative to body } \\
\text { mass }\end{array}$ & $\begin{array}{c}\text { Suggested intake } \\
\text { goals }\end{array}$ \\
\hline Energy, MJ & - & - & 9.2 & 0.1 & 12.7 \\
Carbohydrate, g & 60 & $60-70$ & 351 & 4.2 & 480 \\
Protein, g & 14 & $12-15$ & 77 & 0.9 & - \\
Fat, g & 26 & $20-25$ & 63 & 0.7 & - \\
\hline
\end{tabular}

Table 3 Self-Reported Energy, Macronutrient, and Fluid Intake

\begin{tabular}{lccccc}
\hline & $\begin{array}{c}\text { Percentage } \\
\text { contribution }\end{array}$ & $\begin{array}{c}\text { Mean intake } \\
\text { per day }\end{array}$ & $\begin{array}{c}\text { Relative to } \\
\text { body mass }\end{array}$ & Range & $\begin{array}{c}\text { Suggested } \\
\text { intake goals }\end{array}$ \\
\hline Energy, MJ & - & $8.5 \pm 2.0$ & 0.1 & $2.4-14.3$ (Days 2 and 57) & 12.7 \\
Carbohydrate, g & 58 & $314 \pm 74$ & 3.7 & $93-569$ (Days 2 and 80) & 480 \\
Protein, g & 15 & $76 \pm 23$ & 0.9 & $21-143$ (Days 2 and 52) & - \\
Fat, g & 27 & $62 \pm 23$ & 0.7 & $15-124$ (Days 2 and 46) & - \\
Total fluid, ml & - & $3,612 \pm 1,028$ & 43 & $570-6,052$ (Days 2 and 78) & 3,020 \\
\hline
\end{tabular}


of weighed inventory was used to validate self-reported intake. Hill and Davies reported that when food rations are supplied, similar to this study, subjects report good agreement between EI and EE. Since most snacks were consumed according to the inventory, yet were not all recorded, we were the least confident in the reporting of snack items.

Dependent on energy demands, EI was shown to be inconsistent throughout the voyage in relation to the different oceanic phases (Figure 1). A 10-day moving average demonstrated that EI gradually increased above reported mean intake during the Indian Ocean phase; peaked during the Southern Ocean phase, known for increased physical exertion; and progressively decreased toward the end of the voyage to fluctuate around the mean, adequate to meet requirements for a physical activity level of 1.5. The variation in EI between and within the different phases of the race is potentially explained by the different demands placed on the racer to ensure optimal race pace and likely to have been influenced by the different metrological ranges. For example, the Southern Ocean is known for its harsh weather conditions in comparison with some of the other oceans of the world, which was the case on this occasion. This may have increased EE, thus increasing EI. Furthermore, because the racer understood the demands of the Southern Ocean and had experienced exposure to those conditions she stated that she intentionally increased EI in preparation for an expected increase in EE.

The inventory mean EI (9.2 MJ/day) was similar to the allowance self-selected by the racer. Providing menu plans with more calories allowed scope to avoid menu fatigue since foods were added that were not part of the original food provision. The racer achieved intakes beyond the prescribed goal (12.7 MJ/day) on five occasions (Days 43, 52, and 57 in the South Pacific and Days 72 and 80 in the South Atlantic).

Macronutrient intakes followed a trend similar to that of daily EI, particularly fat (Figure 2). Greater reduction in fat intake was consistent with the lower EI toward the end of the voyage. Food preferences earlier in the race may have resulted in leftover carbohydrate-rich foods for the end of the race. Sports drinks were not consumed until Day 65, and gels and granola were not consumed regularly until Day 75 .

The carbohydrate intake goal was exceeded on four occasions (Figure 2), reflecting some of the highest EI (Days 43 and 57 in the South Pacific and Days 80 and 82 in the South Atlantic).

Figure 3 illustrates the contribution of provisions to food groups and additional supplements (energy gels and sports drinks), beverages, and dehydrated meals. Most foods high in fat and/or sugar were carbohydraterich snack items. Snack items including confectionary (sweets, chocolates, biscuits, and crepes), cereal bars, malt loaf, brioche, dried and fresh fruits, cheese, and drinking chocolate provided a significant contribution toward five of the food groups, providing $25 \%$ of overall EI-greater than the $\sim 15 \%$ contribution observed by
Bigard et al. (1998). A further 7\% of the EI was provided by sports drinks and gels. The significant contribution from snack foods was likely due to their ease of preparation and consumption, as well as the variety offered. Fresh milk and dairy products were used only during the initial stages of the race, because they are perishable, and so did not make a significant contribution over the duration of the race.

\section{Postrace Evaluation}

Postrace discussion regarding the appropriateness of 10-day food bags prompted the racer to comment, "It's quite a big psychological thing," as they worked well and became an exciting focal point of the voyage. "Weekly bags may have become too routine and resulted in saving the same types of food for the different days of the week." The psychological effect was further enforced by hiding treats for special-occasion days.

Weight loss is still considered inevitable in prolonged offshore sailing. Negative energy balance was evidenced by a 7.9-kg loss of body mass. This could have been worse if the nutritional team had accepted the racer's request for a NI of $8.4 \mathrm{MJ} /$ day. The 7.9-kg loss of body mass could be attributed exclusively to fat. This would have represented an energy imbalance of $\sim 3.2 \mathrm{MJ} /$ day over the duration of the 99-day race. In this case the established mean EI of $9.2 \mathrm{MJ} /$ day summed with the equivalent deficit attributed to fat (3.2 MJ/day) summates to an EE of $12.4 \mathrm{MJ} /$ day. This compares well with the negotiated target of 12.7 $\mathrm{MJ} / \mathrm{day}$. The attribution of fat as the major component of body-mass loss is supported by changes in FM and FFM established by DXA before and after the race. Before the race, FM and FFM were measured as $28.0 \mathrm{~kg}$ and 52.8 $\mathrm{kg}$, respectively, and after the race at $23.6 \mathrm{~kg}$ and $52.4 \mathrm{~kg}$, respectively (bone mineral content was $3.1 \mathrm{~kg}$ on both occasions). Thus, the estimated FM loss of $4.4 \mathrm{~kg}$ and FFM loss of $0.4 \mathrm{~kg}$ equated to $4.8 \mathrm{~kg}$ of body mass lost between DXA measurements. Body mass increased by $0.8 \mathrm{~kg}$ between the DXA measurement and the start of the race, and body mass increased by $2.3 \mathrm{~kg}$ postrace, before the final DXA measurement; both gains are likely to be fat. Hence, the 7.9-kg body-mass loss during the race is likely to be a loss of $7.5 \mathrm{~kg}$ of FM $(4.4+0.8+2.3 \mathrm{~kg})$ and $0.4 \mathrm{~kg}$ of FFM. While on average EI and absolute macronutrient recommendations were not attained in absolute values, most of the loss was FM, which suggests that NI was sufficient to promote utilization of the greater part of energy from endogenous fat stores rather than protein stores. We were pleasantly surprised that there was only a small reduction in FFM over the duration of the voyage, which equated to a negative nitrogen balance of $\sim 1 \mathrm{~g} /$ day.

The racer emphasized that recording documents were a useful tool for monitoring NI, in particular fluid because this could be more easily quantified, leading to the racer's consciously making more effort on following days if fluid intake goals were not met. Recording food and fluid as consumed on waterproof paper became routine, with the racer reporting it as therapeutic to update 


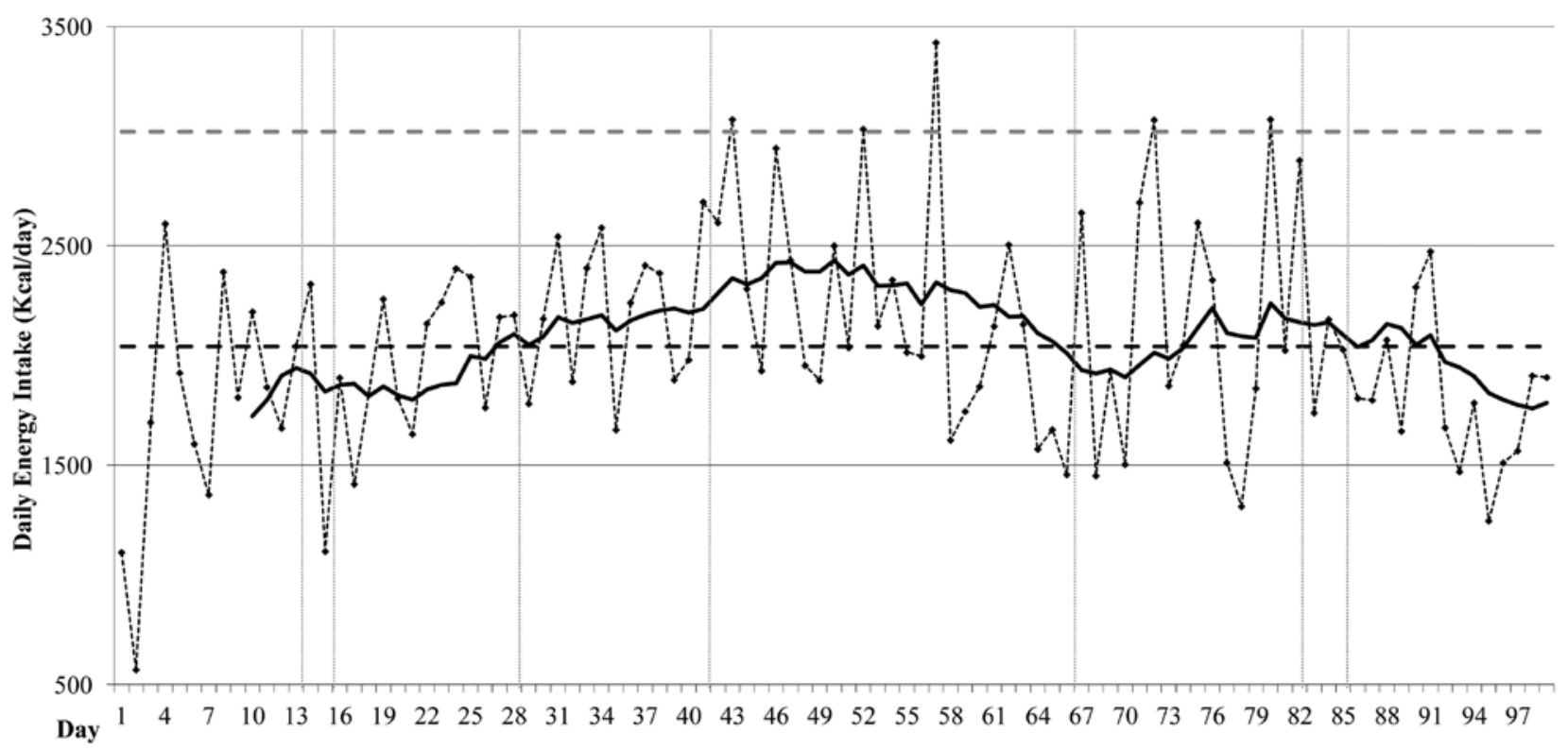

$\begin{aligned} & \text { Oceanic } \\
& \text { Phase }\end{aligned}$
\begin{tabular}{|c|c|c|c|c|c|c|c|} 
North Atlantic & D & South Atlantic & Indian Ocean & South Pacific & South Atlantic & D & North Atlantic \\
\hline
\end{tabular}
\begin{tabular}{|l}
\hline- ---- Reported EI (Kcal/day) \\
\hline
\end{tabular}

Figure 1 - Daily reported energy intake (EI) for the whole voyage. Note. $\mathrm{D}=$ doldrums.

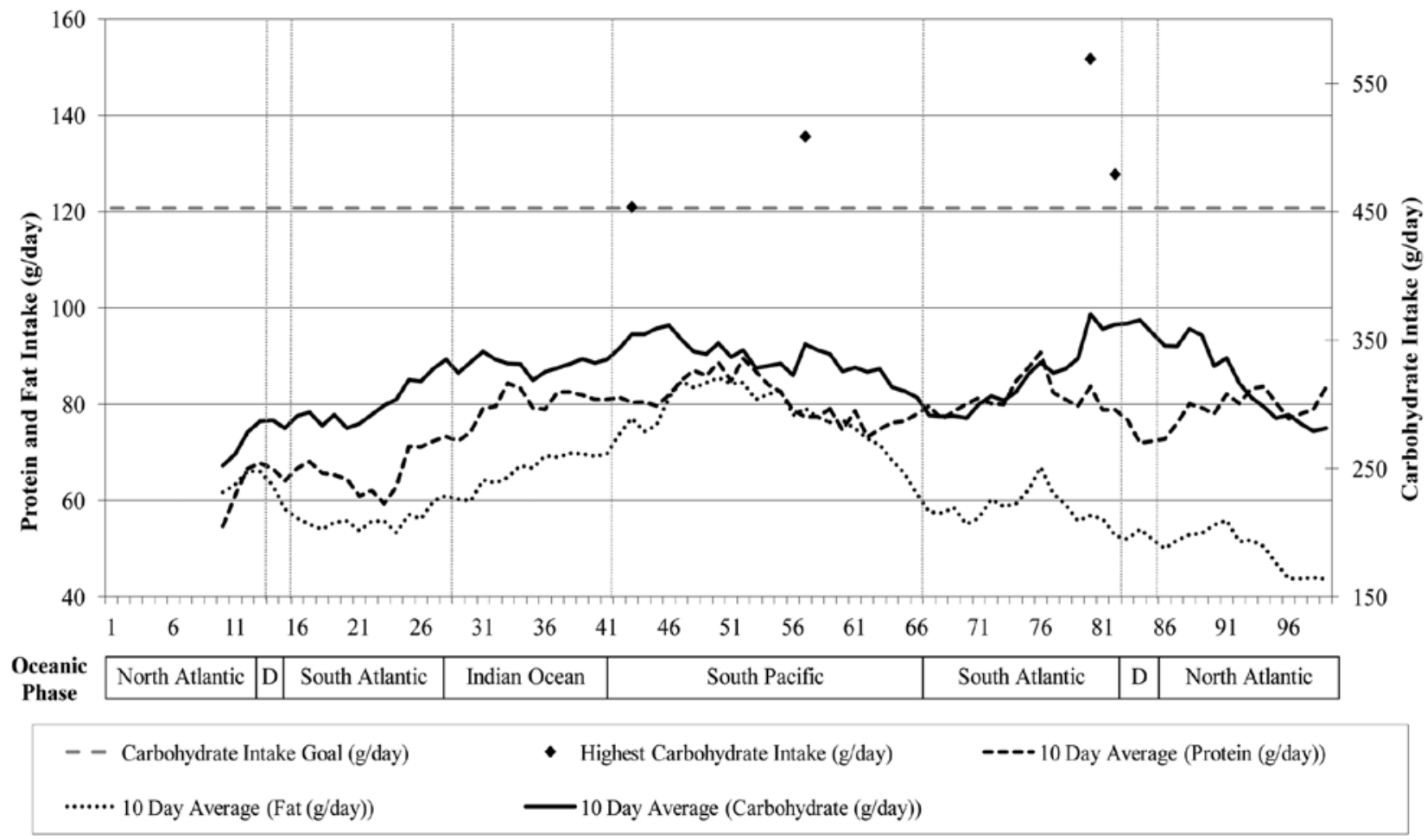

Figure 2 - Reported macronutrient intake for every 10 days across the whole voyage. Note. $\mathrm{D}=$ doldrums. 


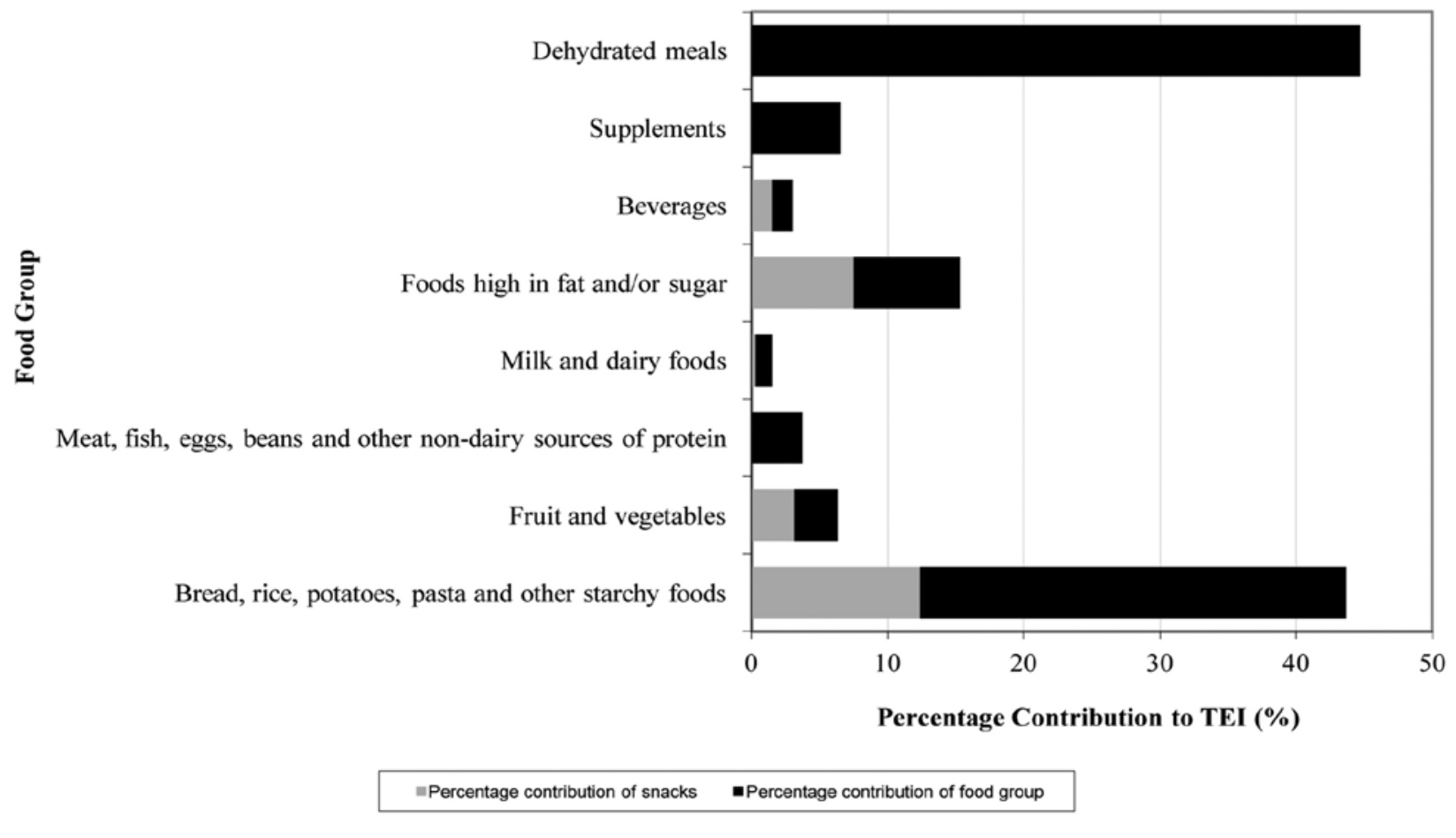

Figure 3 - Percentage contribution of food groups and snacks to total energy intake (TEI) according to the inventory.

electronic recording documents at the end of each day. She commented, "We [the racer and sports nutrition support] made quite a good job of making it easy to do [food record]."

The postrace questionnaire indicated that food preferences changed across the duration of the voyage and menu fatigue was evident. Different food textures were reported to reduce this effect. Snack foods were enjoyed more than main meals but became repetitive. Sweet foods were craved after Cape Horn, which followed the physically demanding period (Southern Ocean) during which glycogen reserves may have been reduced considerably. Chocolate energy gels satisfied this, with the racer attributing cravings to physical and mental fatigue. She expressed strong food preferences in the planning stage because of menu fatigue she had experienced in previous voyages, which limited the range of foods on the menu during the Vendée. Tomato-based freeze-dried meals were a preference before the race but during the voyage were deemed unpalatable, suggesting that food preferences are not always predictable between races. The racer was encouraged to take more calories than she had self-selected allowing more variety in the food provision, thus trying to offset food preference changes experienced during the voyage.

Since it was recommended that energy gels be consumed with water, a higher consumption of gels from the start of the race would have increased initial voluntary fluid intakes, as well as overall EI. Supplements and snacks were generally consumed after physical exertion, and the racer "felt an obvious recovery." While recom- mendations for carbohydrate intake pre-, during, and postexercise are well established, it is difficult to predict in sailing when the next bout of physically demanding work may occur, but increased activity generally reflects heavy winds. The demands of solo sailing place greater importance on recovery nutrition when conditions allow.

Prerace education sensitized the racer to when NI was not optimal. Regular meals and snacks contributed toward "feeling more level headed preventing fatigue" and generally made her "feel much better overall." As routine was developed the racer was able to maintain frequent NI.

\section{Reflection}

Prerace education and nutritional provision was aimed at helping the racer meet prescribed NI goals. It was evident from reported intakes and weight loss that intake goals were not achieved; however, NI was nearly sufficient to maintain FFM (overall loss of only $0.4 \mathrm{~kg}$ ). The specific magnitude of energy imbalance was met primarily by endogenous fat stores, ensuring continued performance with minimal compromise of lean tissue over the duration of the race. The range of intakes show that the racer was able to go beyond prescribed goals on some occasions, suggesting that prerace education was successful in promoting awareness and understanding of goals through recording of dietary intake, bearing in mind that limited self-selected provision only allowed for $8.4 \mathrm{MJ} /$ day for the voyage. 
Establishing highly accurate intakes on a given day is difficult, but the evaluation of overall and 10-day moving averages of NI is possible, especially using preweighed foods in this environment over prolonged periods. The relative accuracy of this method was verified by the food inventory. The combined method enabled eating patterns and timing of intake to be assessed, thus providing important information for optimizing nutritional strategies for ocean racing in the future. Since snack items made a large contribution to total EI, these should be planned more strategically for future voyages. A wider variety that avoids repetition in food bags may positively increase the psychological effects the racer associated with varying food bags. To further increase energy and carbohydrate intake, a more conscious effort to consume carbohydrate supplements from the start of the race would be required. While not all supplements were consumed, the racer acknowledged this as a valuable recovery strategy. Future prerace education may be improved by developing resources that focus on the nutritional content of recovery foods to facilitate achieving the prescribed carbohydrate intake goals. In addition, a simple carbohydrate-content list of foods could be incorporated into the electronic food-recording system to facilitate self-appraisal of daily intakes. The provision of food bags with higher energy content for the Southern Ocean may have led to an increased NI. The use of meal-replacement products, although not deemed practical by this racer, may require further consideration for future voyages as a means of improving the overall nutrient profile.

A sixth-place finish for a first Vendée is a successful performance, but this intervention demonstrates that further work is required to improve the racer's nutrition strategy to facilitate meeting more optimal NI goals.

\section{Acknowledgments}

We would like to express our appreciation to the racer for her enthusiasm for the project and high attention to detail in accurately recording data.

\section{References}

American Dietetic Association; Dietitians of Canada; American College of Sports Medicine, Rodriguez, N.R., Di Marco, N.M., \& Langley, S. (2009). American College of Sports Medicine position stand. Nutrition and athletic performance. Medicine and Science in Sports and Exercise, 41(3), 709-731. PubMed

Bigard, A.X., Guillemot, P., Chauve, J., Duforez, F., Portero, P., \& Guezennec, C. (1998). Nutrient intake of elite sailors during a solitary long-distance offshore race. International Journal of Sport Nutrition, 8, 364-376. PubMed

Black, A.E. (2001). Dietary assessment for sports dietetics. British Nutrition Foundation Nutrition Bulletin, 26, 29-42.

Branth, S., Hambraeus, L., Westerterp, K., Andersson, A., Edsgren, R., Mustelin, M., \& Nilsson, R. (1996). Energy turnover in a sailing crew during offshore racing around the world. Medicine and Science in Sports and Exercise, 28(10), 1272-1276. PubMed doi:10.1097/00005768199610000-00010

Hill, R.J., \& Davies, P.S.W. (2001). The validity of self reported energy intake as determined using the doubly labelled water technique. The British Journal of Nutrition, 85, 415-430. PubMed doi:10.1079/BJN2000281

Kleiner, S.M. (1999). Water: An essential but overlooked nutrient. Journal of the American Dietetic Association, 99, 200-206. PubMed doi:10.1016/S0002-8223(99)00048-6

Loucks, A.B. (2004). Energy balance and body composition in sports and exercise. Journal of Sports Sciences, 22, 1-4. PubMed doi:10.1080/0264041031000140518

Myers, S.D., Leamon, S.M., Nevola, V.R., \& Llewellyn, M.G.L. (2008). Energy expenditure during a single-handed transatlantic yacht race. British Journal of Sports Medicine, 42(4), 285-288. PubMed doi:10.1136/bjsm.2007.041533

Williams, C. (1995) Macronutrients and performance. Journal of Sports Sciences, 13(Suppl 1), 1-10. 